Zeszyty Naukowe Szkoły Głównej Gospodarstwa Wiejskiego w Warszawie

Problemy Rolnictwa Światowego tom 19 (XXXIV), zeszyt 1, 2019: 133-143 DOI: $10.22630 /$ PRS.2019.19.1.12

Anna Twardowska ${ }^{1}$

Szkoła Główna Gospodarstwa Wiejskiego w Warszawie

\title{
Konwergencja typu sigma cen gruntów rolnych w państwach Unii Europejskiej
}

\section{Sigma Convergence of Agricultural Land Prices in European Union Countries} Synopsis. W artykule poruszono problematykę zależności pomiędzy cenami ziemi rolniczej w
państwach Unii Europejskiej. Celem artykułu jest próba uzyskania odpowiedzi na pytanie czy ma
miejsce zmniejszanie się zróżnicowania poziomu cen gruntów rolnych w krajach Unii Europejskiej.
Analizie poddano ceny gruntów rolnych w wybranych państwach UE w latach $2006-2016$. Badaniu
poddano występowanie konwergencji w trzech wymiarach: w całej Unii Europejskiej, pomiędzy
państwami tzw. starej Unii oraz pomiędzy tzw. nowymi krajami UE. W wyniku przeprowadzonych
analiz potwierdzono występowanie zjawiska sigma-konwergencji cen gruntów rolnych w całej UE.
Stwierdzono również, że w tzw. nowych państwach UE oraz pomiędzy państwami należącymi do
tzw. starych państw UE nie zachodzi zjawisko sigma-konwergencji cen gruntów rolnych.

Słowa kluczowe: sigma-konwergencja, grunty rolne, ceny, Unia Europejska

Abstract. The article raises the issue of dependence between agricultural land prices in the European Union countries. The aim of the article is to provide an answer to the following question: if the level of agricultural land price differentiation in the European Union is diminishing. The analysis covered prices of agricultural land in selected the EU countries in the period 2006 - 2016. The study was based on the occurrence of convergence in three dimensions: throughout the European Union, between the so-called old EU and between the so-called new EU countries. As a result of the conducted analyses, the phenomenon of sigma-convergence of agricultural land prices across the EU was confirmed. It was also found that in the so-called new EU countries and in so-called old EU countries there is no sigma convergence of agricultural land prices.

Key words: sigma-convergence, agricultural land, prices, the European Union

JEL Classification: C19, Q15, R10

\section{Wstęp}

Wspólny rynek wewnętrzny Unii Europejskiej przejawia się w swobodnym przemieszczaniu się towarów - dóbr i usług, ale także czynników produkcji (pracy i kapitału). Obok kapitału i pracy, jednym z podstawowych czynników produkcji jest ziemia. Ze względu na specyficzne cechy ziemi, nie jest możliwy transfer z regionów nadwyżkowych do regionów, w których jest odczuwany niedobór tego czynnika. Z uwagi na ten fakt powstaje pytanie, czy ceny ziemi jako czynnika produkcji w poszczególnych regionach są ze sobą powiązane. Podstawą do postawienia twierdzenia dotyczącego

\footnotetext{
${ }^{1}$ Mgr inż., Katedra Ekonomiki Rolnictwa i Międzynarodowych Stosunków Gospodarczych SGGW w Warszawie, ul. Nowoursynowska 166,02-787 Warszawa, e-mail: anna_twardowska@sggw.pl https://orcid.org/0000-0002-6079-3044
} 
wzajemnych powiązań cen ziemi jest, wskazywana w literaturze, przestrzenna integracja na rynku towarów rolnych. Jeżeli ma miejsce integracja na rynku towarów rolnych, to jest ona warunkiem integracji na rynkach czynników produkcji (Krugman i Obstfeld, 2007). Badanym czynnikiem jest ziemia. Integracja na rynku ziemi będzie konsekwencją sytuacji występującej na mobilnych rynkach towarów rolnych. W związku z powyższym oczekuje się, że na podstawie przestrzennej integracji, jaka występuje na rynkach towarów rolnych, będzie miała również miejsce przestrzenna integracja na rynku czynników produkcji, w prezentowanym przypadku - na rynku ziemi rolniczej.

Dotychczasowe badania konwergencji cenowej na rynkach państw Unii Europejskiej sprowadzały się do zbadania integracji rynków towarów rolnych. Liczne prace dowodziły, że rynek towarów rolnych $\mathrm{w}$ Unii Europejskiej podlega procesowi integracji $(\mathrm{m}$. in. Hamulczuk (red.), 2016, Wyrzykowski, 2015, Zawojska, 2012). Rynek ziemi rolniczej jest przedmiotem zainteresowania wielu badaczy. Autorzy publikacji koncentrują się przede wszystkim na obrocie ziemią rolniczą i przemianach agrarnych (m. in. Sikorska, 2013), czynnikach kształtujących ceny ziemi rolniczej (Pietrzykowski, 2014b, Weil, 2003), czy zmianach przepisów prawa wpływających na funkcjonowanie rynku ziemi rolniczej (Gaca, 2017, Prokurat, 2017). W dotychczasowej literaturze brakuje publikacji, w których podejmowano by temat konwergencji cen ziemi w UE.

$\mathrm{W}$ artykule poruszono problematykę integracji rynków ziemi rolniczej w państwach Unii Europejskiej. Celem artykułu jest próba uzyskania odpowiedzi na pytanie, czy ma miejsce zmniejszanie się zróżnicowania poziomu cen gruntów rolnych w czasie w krajach Unii Europejskiej. Tym samym weryfikowano występowanie zjawiska konwergencji typu sigma. Ponadto, przedstawiono zmiany cen gruntów rolnych, jakie zaszły w badanym okresie w państwach Unii Europejskiej oraz podjęto próbę odpowiedzi na pytanie dotyczące przyczyn zaistniałych zmian.

\section{Konwergencja w teorii ekonomii}

Od końca XX wieku analiza konwergencji jest jednym z głównych nurtów badań dotyczących teorii wzrostu. Zgodnie z tradycyjnym podejściem, konwergencja odpowiada na pytanie dotyczące zmniejszania się zróżnicowania poziomu rozwoju gospodarek (sigmakonwergencja) lub dotyczy zmniejszania się zróżnicowania pomiędzy regionami o początkowo niższym poziomie rozwoju a regionami lepiej rozwiniętymi ( $\beta$-konwergencja). Koncepcja betakonwergencji zakłada występowanie tzw. zjawiska „doganiania” - to oznacza, że regiony o niższym poziomie rozwoju charakteryzują się szybszym tempem wzrostu niż kraje bogatsze, co wraz z upływem czasu prowadzi do wyrównywania poziomów dochodów per capita (Berbeka, 2006). W ramach koncepcji konwergencji typu beta wyróżnia się ponadto konwergencję absolutną (zakładająca, że kraje słabiej rozwinięte zawsze wykazują szybsze tempo wzrostu, dążąc do poziomu krajów wyżej rozwiniętych) oraz konwergencję warunkową (oznaczającą osiaganie zbieżności tylko w takim przypadku, gdy wszystkie regiony, zarówno te gorzej jak i lepiej rozwinięte, dażą do swoich własnych stanów równowagi długookresowej) (Próchniak, 2006).

Konwergencja gospodarcza oznaczająca osiąganie spójności (zbliżania się) poziomów produkcji per capita wywodzi się z neoklasycznej teorii wzrostu powstałych w latach 50. i 60. XX wieku. Jest następstwem przyjętej w tej teorii koncepcji o malejącej krańcowej produkcyjności kapitału per capita oraz o egzogenicznym podłożu postępu 
technologicznego (Nowak, 2006). Według powyższego, wzrost gospodarczy powinien przybliżać do długookresowego stanu równowagi wyznaczonego przez stope wzrostu. Stopa wzrostu natomiast jest uzależniona od siły roboczej oraz tempa postępu technicznego. Malejąca krańcowa produktywność determinuje również fakt, że stopa wzrostu słabiej rozwiniętych gospodarek jest wyższa, zatem poziom dochodu lub PKB per capita powinien zbliżać się do poziomu gospodarek państw zamożnych (Tylec, 2017). Chronologicznie, pierwszą koncepcją która podlegała rozważaniom była teoria beta konwergencji. Od lat 80 ubiegłego wieku naukowcy zaczęli jednak zwracać uwagę na fakt sprzeczności pojawiającej się $\mathrm{w}$ badaniach, a mianowicie, że występowanie betakonwergencji nie musi oznaczać, że w badanym okresie nastąpi zmniejszenie zróżnicowania danego zjawiska (Kusideł, 2013). Na bazie tych rozważań powstała koncepcja sigma-konwergencji, badająca zmiany zróżnicowania danego zjawiska w czasie. Przy czym, występowanie $\beta$-konwergencji jest czynnikiem koniecznym, ale niewystarczającym do osiagnięcia $\sigma$-konwergencji (Bal-Domańska, 2009).

W literaturze wielokrotnie podejmowano temat zmniejszania się zróżnicowania poziomu rozwoju gospodarczego państw Unii Europejskiej. Wielu badaczy na podstawie przeprowadzonym badań empirycznych potwierdzało zachodzenie procesu konwergencji gospodarczej typu sigma pomiędzy państwami UE (m. in. Jóźwik, 2014, Berbeka, 2006).

Ze względu na przedmiot badania jednym $\mathrm{z}$ rodzajów konwergencji jest tzw. konwergencja nominalna, która oznacza zmniejszanie się poziomów zróżnicowania m. in. cen czynników produkcji, stóp procentowych, czy kursów walutowych (Gnat, 2014). W teorii ekonomii zmniejszenie dyspersji rozwojowej pomiędzy krajami słabiej i lepiej rozwiniętymi powoduje, że konwergencja realna powinna prowadzić do konwergencji nominalnej, co objawia się wyrównaniem poziomów cen (Pietrzykowski, 2014a). Zatem, zgodnie z literatura, proces integracji gospodarczej powinien prowadzić do zbieżności poziomów cen. Podstawą rozważań teoretycznych konwergencji cenowej jest prawo jednej ceny. Prawo jednej ceny stanowi, że na konkurencyjnych rynkach (bez uwzględniania kosztów transportu i oficjalnych barier handlowych) homogeniczne dobra, po przeliczeniu na wspólną walutę, są nabywane po jednakowej cenie (Dzik-Walczak, 2014).

\section{Źródła danych i metodyka}

Dla zrealizowania celu artykułu, zbadano występowanie zjawiska sigmakonwergencji. Zgodnie $\mathrm{z}$ definicja, konwergencja typu sigma to koncepcja oznaczająca zmniejszanie się nierówności badanej cechy w czasie (Kusideł, 2013).

Weryfikacja założenia o występowaniu konwergencji typu sigma wymaga określenia miary koncentracji lub nierówności zjawiska. W literaturze dotyczącej konwergencji zdefiniowanych zostało wiele metod pomiaru tego procesu, różniących się trudnością w zastosowaniu, czy poziomem spełnienia układu aksjomatów stawianych przed miarami nierówności (Kusideł, 2013). Najprostszym miernikiem, stosowanym często w porównaniach państw, jest rozstęp. Jest to prosta do określenia miara, jednak obarczona wadą uwzględniania jedynie dwóch krańcowych danych - najwyższej i najniższej wartości badanego zjawiska. W celu uwzględnienia wszystkich wartości badanych zjawisk w czasie, do obliczenia sigma-konwergencji, najczęściej stosowaną miarą jest współczynnik zmienności lub odchylenie standardowe logarytmów. W literaturze wskazywane są także inne wskaźniki pozwalające określić nierównomierności rozkładu badanej cechy, m. in. 
analiza zmian w czasie współczynnika Giniego czy metoda polegająca na porównaniu poziomów cechy w górnym i dolnym kwintylu rozkładu (Nowak, 2006).

W niniejszym artykule, do weryfikacji hipotezy o występowaniu sigma-konwergencji, zastosowano analizę odchyleń standardowych logarytmów naturalnych danej cechy. Zgodnie $\mathrm{z}$ definicją, do pomiaru sigma-konwergencji w okresie $\mathrm{t}(\mathrm{t}=1,2, \ldots, \mathrm{T})$ stosowane jest odchylenie standardowe logarytmów naturalnych poziomu produktu $y_{i t}$ do wartości średnich w okresie $t$ zgodnie ze wzorem (Bal-Domańska, 2009, s. 10):

$$
\sigma=\frac{\sqrt{\sum_{i=1}^{N}\left(\ln y_{i t}-\ln \bar{y}_{t}\right)^{2}}}{(N-1)}
$$

gdzie: $y_{i t}$ - wartość cechy $y$ dla obiektu $i$, w okresie $t$,

$\bar{y}_{t}-$ średnia arytmetyczna cechy $y_{i}$ (dla $i=1, \ldots, N$ obiektów) dla okresu $t$,

$N$ - liczba badanych obiektów $n=1,2, \ldots, N$.

O występowaniu konwergencji typu sigma mówi się, jeżeli odchylenie standardowe logarytmów naturalnych z okresu na okres maleje. Przeciwny proces do konwergencji jest nazywany dywergencja.

W celu weryfikacji występowania sigma-konwergencji, analizie poddano dwadzieścia wybranych państw Unii Europejskiej, dla których posiadano dane na temat wysokości średnich cen gruntów rolnych. Informacje na temat średnich cen gruntów rolnych pozyskano z danych publikowanych przez Eurostat oraz z publikacji Instytutu Ekonomiki Rolnictwa i Gospodarki Żywnościowej Państwowego Instytutu Badawczego (IERiGŻ PIB), opublikowane w opracowaniach „Rynek ziemi rolniczej. Stan i perspektywy”. Powyższe dane dla poszczególnych państw gromadzone przez IERiGŻ pochodziły nie tylko z państwowych urzędów statystycznych, ale również z takich źródeł jak ministerstwa rolnictwa, ośrodki naukowo-badawcze, instytucje i organizacje rolne oraz agencje pośrednictwa $\mathrm{w}$ obrocie gruntami rolnymi w poszczególnych krajach. W celu zbadania występowania zjawiska konwergencji, uznano, że uzyskane dane wtórne zamieszczone w ww. publikacjach są wystarczające do potwierdzenia lub odrzucenia hipotezy o istnieniu sigma-konwergencji.

Badaniu poddano występowanie konwergencji w trzech wymiarach: w całej Unii Europejskiej (przyjmując do analizy 20 państw); pomiędzy państwami tzw. starej Unii oraz pomiędzy tzw. nowymi krajami UE. Jako nowe państwa Unii Europejskiej przyjęto kraje, które przystapiły do Wspólnoty po 2004 roku. Okres badania ustalono na lata 2006 - 2016.

\section{Rynek ziemi rolniczej w Unii Europejskiej}

Instytucje odpowiedzialne za rynek ziemi rolniczej mają w Unii Europejskiej długą historię. Początki zainteresowania gruntami rolnymi sięgają 1957 roku, kiedy to powstała Wspólna Polityka Rolna - zgodnie z postanowieniami Traktatu Rzymskiego włączono rolnictwo do wspólnego rynku Europejskiej Wspólnoty Gospodarczej (Prokurat, 2017). Głównymi celami WPR były stabilizacja rynków rolnych, poprawa warunków życia rolników i zwiększenie produktywności rolnictwa (Chotkowski i Gaziński, 2011). Proponowane były różne rozwiązania mające na celu wsparcie europejskiego rolnictwa. Stopniowo tworzono instytucje, które miały zapewnić stałą pomoc rolnictwu w Unii Europejskiej - ostatecznie powstał model rolnictwa, który przewiduje ingerencję państwa w rynek. Regułę Traktatu o funkcjonowaniu Unii Europejskiej stanowiąca, że traktaty nie 
przesądzają zasad prawa własności w państwach członkowskich, wiele państw UE wykorzystuje do opracowania własnych przepisów prawnych dotyczących obrotu gruntami rolnymi. Zatem, w niektórych państwach Unii, ceny gruntów, zasady obrotu rynkowego czy warunki dzierżawy mogą być regulowane (Prokurat, 2017).

Państwa Unii Europejskiej są znacznie zróżnicowane pod względem ogólnej powierzchni, a co za tym idzie, także pod względem powierzchni gruntów użytkowanych rolniczo (rys. 1). Do państw o największych obszarach gruntów rolnych należy zaliczyć Francję, Hiszpanię, Niemcy, Rumunię, Polskę, Włochy oraz Wielką Brytanię. Według danych Eurostat powierzchnia gruntów użytkowanych rolniczo w Polsce w 2015 roku wynosiła ponad 150 tys. $\mathrm{km}^{2}$, co stanowiło około 50\% powierzchni kraju. Państwa o najmniejszym areale gruntów ziemi rolniczej to państwa niewielkie powierzchniowo, takie jak Słowacja, Łotwa, Estonia, Belgia, Holandia. Najmniejszy procentowy udział gruntów użytkowanych rolniczo w ogólnej powierzchni kraju odnotowano w państwach skandynawskich - Finlandii i Szwecji. Natomiast największy udział - w Danii, Irlandii, na Węgrzech oraz w Rumunii - w tych państwach ziemia wykorzystywana na cele związane z rolnictwem stanowi ok. $60 \%$ powierzchni całkowitej tych państw.

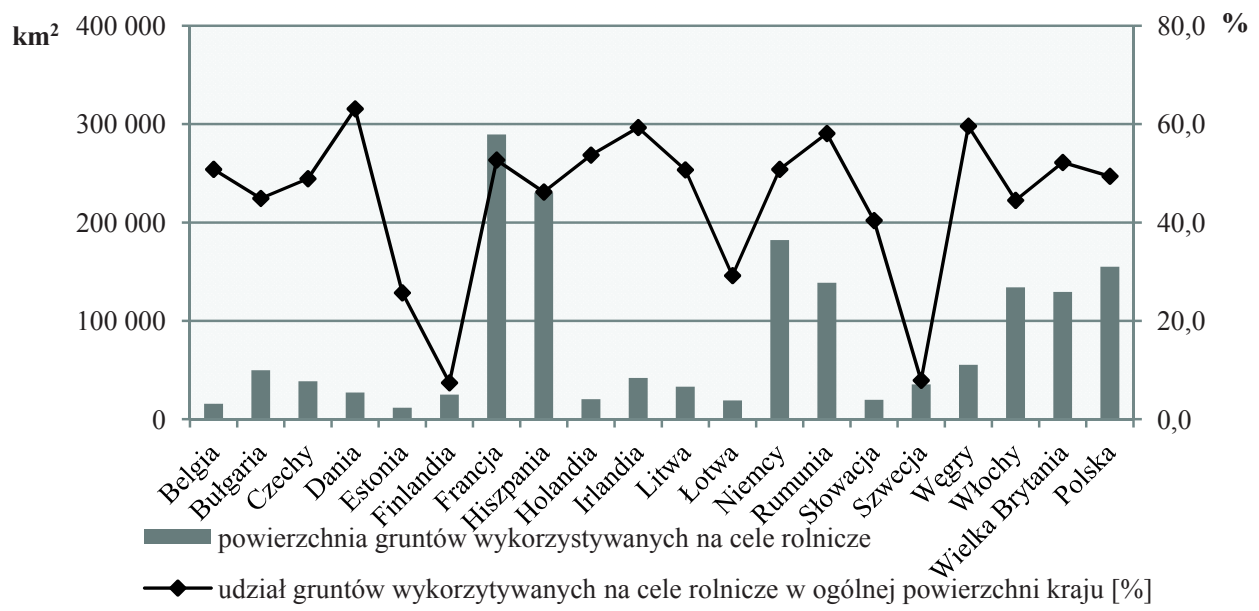

Rys. 1. Powierzchnia gruntów wykorzystywanych na cele rolnicze oraz udział gruntów wykorzystywanych na cele rolnicze w ogólnej powierzchni kraju w wybranych państwach Unii Europejskiej (w 2015 r.).

Fig. 1. The agricultural land area and share agricultural land in the country's total area in selected EU countries (in 2015).

Źródło: opracowanie własne na podstawie danych Eurostat

Polska na tle innych państw Unii Europejskiej jest uznawana jako kraj średnio wyposażony w zasoby ziemi rolnej (Dzun i Musiał, 2013). Powierzchnia ziemi wykorzystywanej na cele rolnicze w Polsce stanowiła w 2015 r. około 8\% zasobu całej UE. Większą powierzchnią ziemi rolniczej dysponowały Francja, Hiszpania i Niemcy.

Ceny gruntów rolnych charakteryzują się dużym zróżnicowaniem pomiędzy poszczególnymi państwami Unii Europejskiej (rys. 2). W roku 2006 najwyższe ceny odnotowano w takich państwach jak Holandia, Belgia, Dania i Irlandia. W tych państwach ceny oscylowały w granicach 27 tys. -37 tys. euro za 1 ha gruntu. Najniższe średnie ceny gruntów rolnych zaobserwowano na Litwie, Łotwie, w Estonii, Czechach, czy Bułgarii. W 
tych państwach w 2006 roku ceny gruntów rolnych wahały się w granicach od 486 do około 1000 euro/ha. Średnia cena ziemi rolniczej we wszystkich badanych państwach UE w 2006 roku wynosiła 9636 euro/ha.

W 2016 roku sytuacja kształtowała się podobnie - tzn. z reguły wyższe ceny występowały w państwach Europy Zachodniej - zdecydowanie najwyższe średnie ceny gruntów zaobserwowano w Holandii (ok. 58 tys. euro/ha). Rok 2016 nie był w tym względzie wyjątkowy - w Holandii od wielu lat są notowane najwyższe ceny gruntów. Ekonomiczne warunki funkcjonowania rolnictwa w Holandii, w szczególności otwarcie na konkurencję światową spowodowały wzrost popytu na grunty, co doprowadziło do wysokiego poziomu cen. Nie bez znaczenia pozostaje fakt, że Holandia jest niewielkim obszarowo państwem, a na jej terytorium obserwuje się ekspansję obszarów zurbanizowanych. Pozyskanie gruntów stało się przedmiotem konkurencji między sektorem rolnym a sektorami budownictwa czy infrastruktury (Rynek ziemi rolniczej... 2017). Powyżej średniej ceny wśród badanych państw (w 2016 roku średnia cena wyniosła 13815 euro/ha), znalazły się również takie kraje jak Belgia, Niemcy, Dania, Irlandia, Włochy, czy Wielka Brytania.

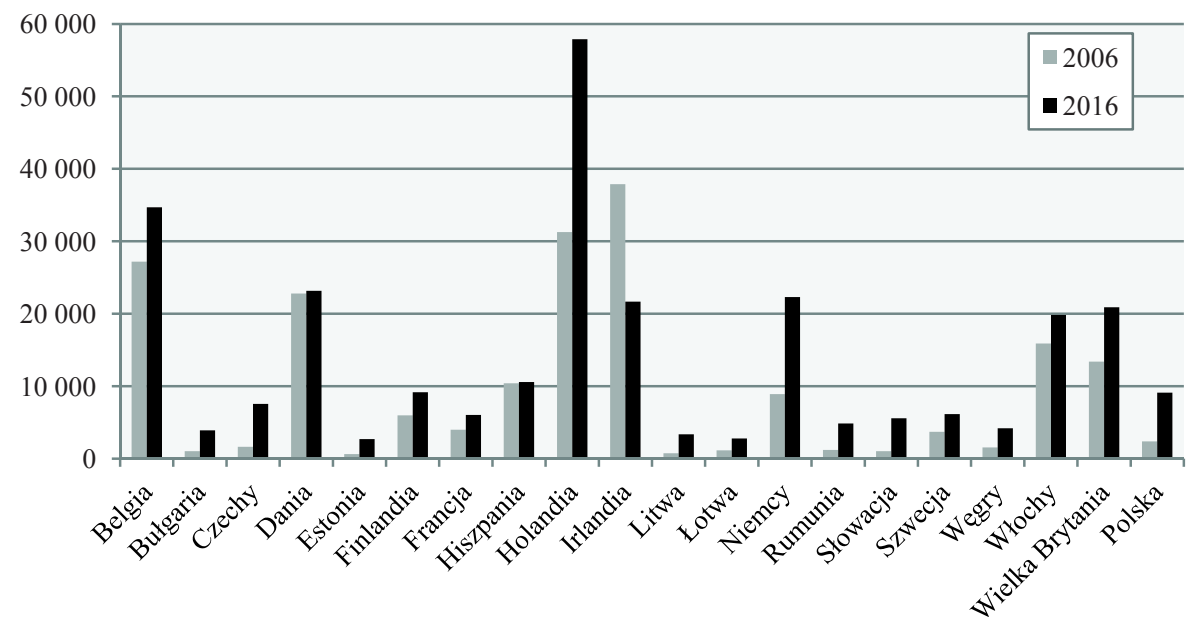

Rys. 2. Średnie ceny ziemi rolniczej w wybranych państwach Unii Europejskiej w latach 2006 i 2016.

Fig. 2. The average agricultural land prices in EU countries in 2006 and 2016.

Źródło: opracowanie własne na podstawie danych IERGiŻ.

Najniższe jednostkowe stawki za grunty rolne uzyskiwano w państwach Europy środkowej i wschodniej. Najniższe ceny odnotowano w Estonii (2 700 euro/ha), Łotwie (2 771 euro/ha), Bułgarii (3 890 euro/ha) oraz na Litwie (3 340 euro/ha).

We wszystkich $\mathrm{z}$ badanych państw $\mathrm{w}$ analizowanym okresie nastąpił wzrost cen gruntów rolnych. Wyjątkiem jest Irlandia, gdzie odnotowano spadek cen gruntów rolnych. Przyczyny takiego stanu należy upatrywać w nagłym wzroście popytu na grunty przeznaczane na cele budowlane i inwestycyjne, który nastąpił w 2006 roku. Wówczas ceny ziemi rolnej wahały się w przedziale 55-65 tys. euro/ha. Wejście gospodarki kraju w fazę recesji w 2008 roku spowodowało spadek popytu na grunty rolne. W efekcie średnia cena spadła poniżej 24,0 tys. euro/ha.

Biorąc pod uwagę ceny gruntów rolnych w Unii Europejskiej, rynek gruntów można podzielić na dwie grupy: 
- tzw. „stare” kraje Unii Europejskiej - w większości z tych państw średnie ceny gruntów rolnych od lat utrzymują się na stabilnym, wysokim poziomie, dominują transakcje wolnorynkowe. Na zmiany cen ziemi wpływ ma przede wszystkim sytuacja gospodarcza danego kraju oraz popyt na grunty w celach lokacyjnych.

- tzw. „nowe” kraje Unii Europejskiej (państwa, które przystąpiły do UE po 2004 roku) sytuacja na tych rynkach jest dynamiczna i zależy od specyfiki danego kraju, w większości z nich po przystąpieniu do UE nastąpił znaczny wzrost cen gruntów rolnych oraz ożywienie na rynku.

\section{Wyniki badań empirycznych}

W Unii Europejskiej zauważa się znaczne zróżnicowanie poziomu oraz dynamiki zmian cen gruntów rolnych. Do czynników wpływających na kształtowanie się poziomu cen gruntów w poszczególnych krajach należy zaliczyć ich dostępność na rynku (uwarunkowaną m.in. zasobami, w tym udziałem tych gruntów w ogólnej powierzchni kraju), oraz regulacjami prawnymi poszczególnych państw w zakresie zasad obrotu gruntami rolnymi (Laskowska, 2014). Analizując zmiany w poziomach cen, jakie nastapiły w badanym okresie stwierdzono, że ziemia rolnicza w państwach tzw. „starej” UE zyskuje wolniej na wartości niż grunty rolne w państwach przyjętych do Wspólnoty po 2004 roku.

W zakresie występowania zjawiska konwergencji, analizie poddano integrację rynku gruntów rolnych w całej Unii Europejskiej (rys. 3). Odchylenia standardowe logarytmów naturalnych z okresu na okres są coraz mniejsze. Linia trendu o nachyleniu ujemnym jest istotna statystycznie. Zatem, występuje zjawisko sigma-konwergencji.

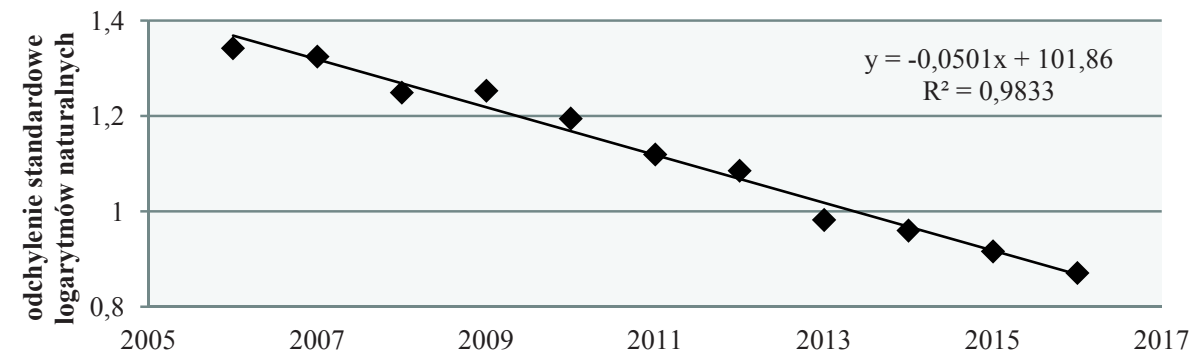

Rys. 3. Konwergencja typu sigma pomiędzy cenami gruntów rolnych w państwach UE.

Fig. 3. Sigma convergence of agricultural land prices in European Union countries.

Źródło: opracowanie własne na podstawie wyników badań.

Uzasadnieniem występowania sigma-konwergencji jest dynamiczny wzrost cen ziemi w nowych państw członkowskich (w szczególności na Słowacji, w Czechach, Bułgarii czy w Polsce) oraz w miarę stabilny poziom cen ziemi w państwach tzw. starej Unii (przede wszystkim w Belgii, Danii, Francji, we Włoszech). W państwach, które przystappiły do UE po 2004 roku, znaczny wzrost cen prowadzi do systematycznego „doganiania” cen występujących w państwach już wcześniej należących do Unii. Te dwa zjawiska dynamiczny wzrost cen w nowych państwach UE oraz względna stabilizacja na rynkach państw tzw. starej UE - występujące jednocześnie, prowadzą do stopniowego zmniejszania zróżnicowania poziomu cen ziemi rolniczej w Unii Europejskiej. 
W odniesieniu do państw należących do Unii Europejskiej przed 2004 r., w początkowym okresie badania, tj. od 2007 do 2011 roku, następowało zmniejszenie zróżnicowania poziomów cen ziemi rolniczej w tych państwach (rys. 4). Od 2011 do 2016 roku nastąpiła stabilizacja na rynku ziemi rolniczej - w zakresie analizy logarytmów naturalnych nie występowały zmiany - wzrost lub spadek wartości poziomów odchyleń. Linia trendu badanego zjawiska jest nachylona ujemnie, oraz jest istotna statystycznie, co może świadczyć o zachodzącym zjawisku sigma-konwergencji. Warto dodać, że zmniejszenie różnic cenowych nastąpiło w sposób skokowy na przełomie lat 2009-2010 i od tego czasu procesy sigma-konwergencji nie są widoczne.

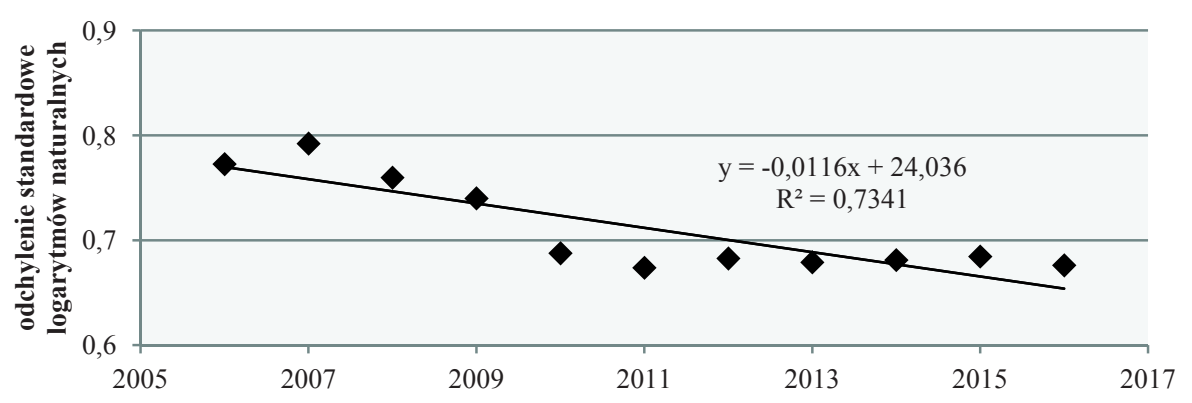

Rys. 4. Konwergencja typu sigma pomiędzy cenami gruntów rolnych w państwach tzw. starej UE.

Fig. 4. Sigma convergence of agricultural land prices in so-called old European Union countries.

Źródło: opracowanie własne na podstawie wyników badań.

Rysunek 4 dotyczy wszystkich państw, które zaliczono do tzw. „starej” Unii. W toku przeprowadzonych analiz zweryfikowano również zmiany poziomów odchyleń standardowych logarytmów naturalnych, przy uwzględnieniu jedynie państw, w których nastapił wzrost cen gruntów rolnych w badanym okresie. Jedynym przypadkiem, nieodpowiadającym powyższemu kryterium jest Irlandia, w której w latach 2006 - 2016 odnotowano spadek cen ziemi rolniczej. Irlandia jest jedynym państwem, w którym zaobserwowano odmienną tendencję od pozostałych państw, zatem zdecydowano się na wyeliminowanie tej zmiennej oraz sprawdzenie, czy wpłynie to znacząco na otrzymane wyniki (rys. 5).

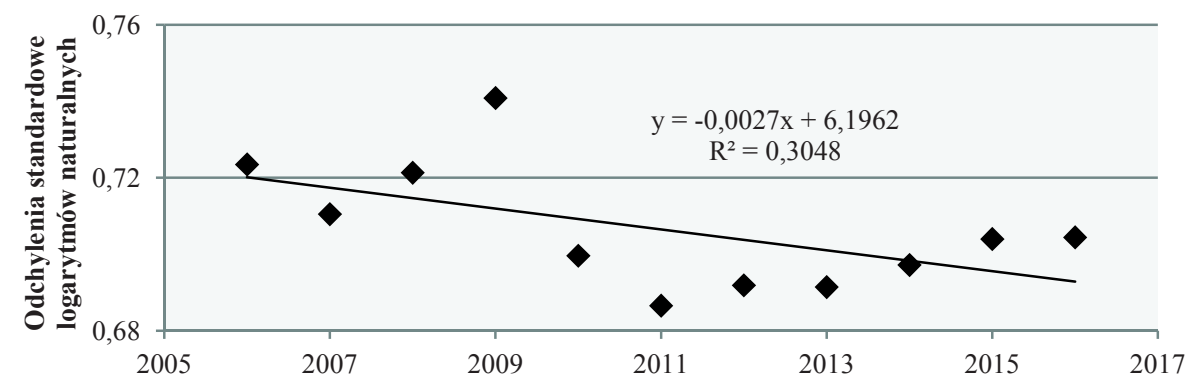

Rys. 5. Konwergencja typu sigma pomiędzy cenami gruntów rolnych w tzw. starych państwach UE, po wyeliminowaniu Irlandii.

Fig. 5. Sigma convergence of agricultural land prices in so-called old European Union countries (without Ireland).

Źródło: opracowanie własne na podstawie wyników badań. 
Wykres 5 również potwierdza skokowy charakter zmniejszenia różnic cenowych. Przy uwzględnieniu tzw. „starych” państw należących do UE, w których w badanym okresie następował wzrost cen ziemi rolniczej, linia trendu jest nachylona ujemnie, ale jest nieistotna statystycznie ( $p$-value na poziomie 0,078 ). W związku $\mathrm{z}$ faktem, że po wyeliminowaniu wyłącznie jednej zmiennej wyniki nie spełniają kryterium istotności, przyjęto, że w państwach „starej” Unii nie wystąpiła w badanym okresie konwergencja typu sigma między cenami gruntów rolnych.

Do „nowych” państw Unii Europejskiej zaliczono Bułgarię, Czechy Estonię, Litwę, Łotwę, Rumunię, Słowację, Węgry oraz Polskę. Pomiędzy cenami gruntów rolnych w tych krajach, w okresie objętym analiza, miało miejsce mniejsze zróżnicowanie cen gruntów (rys. 6), czego efektem jest niższy poziom odchyleń standardowych logarytmów naturalnych niż w przypadku całej UE (rys. 3) i „starej” UE (rys. 4 i 5).

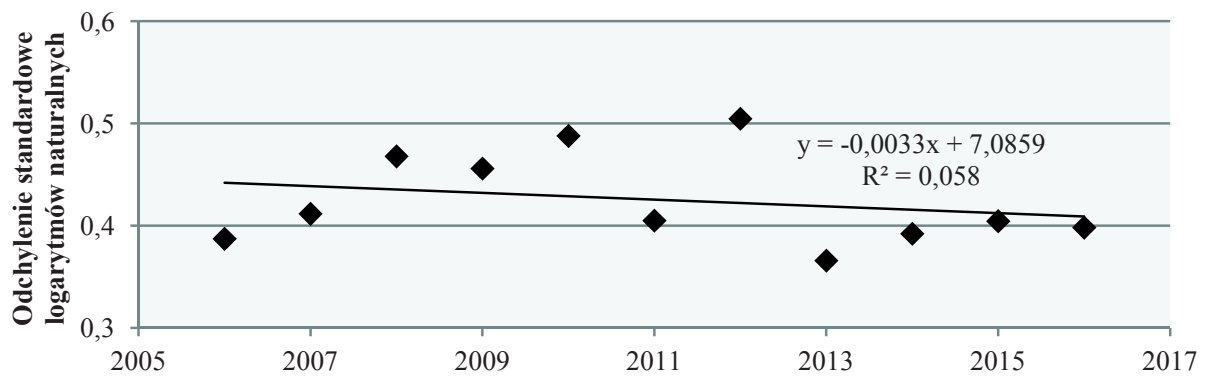

Rys. 6. Konwergencja typu sigma pomiędzy cenami gruntów rolnych w tzw. nowych państwach UE.

Fig. 6. Sigma-convergence of agriculture land prices in so-called new European Union countries.

Źródło: opracowanie własne na podstawie wyników badań.

W „nowych” państwach UE, trend liniowy wykazujący łagodne ujemne nachylenie, dla badanego okresu jest nieistotny statystycznie. Zatem nie zachodza przesłanki do potwierdzenia występowania sigma-konwergencji. Brak wyraźnej tendencji czasowej zjawiska oraz coroczne wahania świadczą o dynamicznej sytuacji na rynku gruntów rolnych w "nowych” państwach UE i niejednolitych zmianach cen na tych rynkach. W badanym okresie nie zaobserwowano też występowania zjawiska przeciwnego, tzn. dywergencji cen.

\section{Podsumowanie}

Ceny gruntów rolnych w badanym okresie wzrosły we wszystkich analizowanych krajach UE (z wyjątkiem Irlandii). Wyższy procentowy wzrost cen zaobserwowano w tzw. „nowych” państwach UE, które przystapily do Wspólnoty po 2004 roku - wejście nowych państw do Unii Europejskiej spowodowało w tych krajach znaczny wzrost cen gruntów rolnych. Tempo i skala wzrostu cen gruntów rolnych w państwach tzw. „starej UE” jest mniejsze. Pomimo znacznego wzrostu cen gruntów rolnych w nowych państwach Unii Europejskiej, nadal zauważalne są dysproporcje pomiędzy cenami gruntów w tzw. nowych i starych państwach Unii. W żadnym z ,nowych” państw UE ceny gruntów rolnych nie przekroczyły średniej ceny gruntów rolnych dla całej Unii Europejskiej. 
Na podstawie przeprowadzonej analizy, można uznać, że dla całej Unii Europejskiej występuje zjawisko konwergencji cenowej typu sigma. Następuje bowiem zjawisko zmniejszania się zróżnicowania poziomów cen gruntów rolnych między krajami w UE. Występujące zjawisko związane jest z dynamicznym wzrostem cen ziemi nowych państw członkowskich oraz ze stabilnym poziomem cen ziemi w państwach tzw. starej Unii. Dynamiczny wzrost cen w nowych państwach UE oraz względna stabilizacja na rynkach państw tzw. starej UE prowadzą do stopniowego zmniejszania zróżnicowania poziomu cen ziemi rolniczej w Unii Europejskiej. Przeprowadzone badania nie potwierdzily występowania zjawiska konwergencji typu sigma pomiędzy tzw. nowymi państwami Unii Europejskiej. W przypadku krajów „starej” Unii badania nie były jednoznaczne, a ich wyniki w znacznym stopniu determinowane były nietypowym przebiegiem cen w Irlandii.

Ostateczna konkluzja sprowadza się do uznania postępującej integracji na rynku ziemi rolniczej w UE. Mimo braku mobilności ziemi, jako czynnika produkcji, obserwujemy wyrównywanie się jego cen. Wynikać to może z praktycznie nieograniczonego przepływu towarów rolno-żywnościowych oraz przepływu kapitału. Brak istotnej konwergencji cen typu sigma w grupie „starych” i w grupie „,nowych” krajów członkowskich wskazywać może na występowanie granic dla pełnej integracji rynków ziemi rolniczej w krajach UE. Przypuszczenia te warto zweryfikować w przyszłości poprzez sprawdzenie występowania zjawiska absolutnej i względnej konwergencji cen typu beta.

\section{Literatura}

Bal-Domańska, B. (2009). Ekonometryczna analiza sigma i beta konwergencji regionów Unii Europejskiej (Econometric analysis of sigma and beta Convergence in the European Union Regions). Prace Naukowe Uniwersytetu Ekonomicznego we Wrocławiu, 76, 9-24.

Berbeka, J. (2006). Konwergencja gospodarcza a konwergencja społeczna krajów Unii Europejskiej (15) w latach 1985-2002 (Economic and Social Convergence of EU Countries (15) in years 1985-2002). Nierówności Społeczne a Wrrost Gospodarczy, 8, 267-280.

Chotkowski, J., Gaziński, B. (2011). Drogi i bezdroża Wspólnej Polityki Rolnej (Proper Tracts vs. Leading Astray of the Common Agricultural Policy). Studia Europejskie, 4, 55-71.

Dzik-Walczak, A. (2014). Tempo konwergencji cenowej w krajach Unii Europejskiej (The pace of price convergence in the countries of the European Union). Ekonomia, 36, 91-123.

Dzun, W., Musiał, W. (2013). Zagospodarowanie ziemi rolniczej w Polsce w okresie przed- i poakcesyjnym w ujęciu regionalnym (The regional dimension of agricultural land development in Poland in pre- and postaccession periods). Wieś i Rolnictwo, 4(161), 62-78.

Gaca, R. (2017). Rynek nieruchomości rolnych w obliczu zmian przepisów prawa na przykładzie wybranych obszarowo rynków lokalnych (Agricultural real estate market in the face of law provisions change on the basis of chosen local markets). W: Nieruchomość w przestrzeni 3. Wydawnictwo Państwowej Wyższej Szkoły Zawodowej w Kaliszu, 121-138.

Gnat, S. (2014). Konwergencja cenowa na lokalnych rynkach nieruchomości w aglomeracji Szczecińskiej w latach 2008-2013 (Price Convergence of local property market in Szczecin Metropolitan Area in 2008-2013), Studia i Prace Wydziału Nauk Ekonomicznych i Zarzqdzania, 36, 213-225.

Hamulczuk, M. (red.) (2016). Ceny żywności w Polsce i ich determinanty (Food prices in Poland and its determinants). IERiGŻ-PIB, Warszawa.

Jóźwik, B. (2014). Konwergencja gospodarcza w regionach państw członkowskich Unii Europejskiej z Europy środkowo-wschodniej (Economic Convergence in the regions of the European Union member states in EastCentral Europe). Roczniki Ekonomii i Zarzqdzania, 6(42), 93-113.

Krugman, P., Obstfeld, M. (2007). Ekonomia międzynarodowa. Teoria i polityka. t. 1 (International economics. Theory and Policy). Wydawnictwo PWN, Warszawa.

Kusideł, E. (2013). Konwergencja gospodarcza w Polsce i jej znaczenie w osiąganiu celów polityki spójności (Economic convergence in Poland and its importance in achieving the objectives of cohesion policy). Wyd. Uniwersytetu Łódzkiego, Łódź. 
Laskowska, E. (2014). Rynek gruntów rolnych w Polsce na tle rynku europejskiego (The market of agricultural land in Poland in the European market). Problemy Rolnictwa Światowego, 14(3), 140-149.

Nowak, W. (2006). Koncepcje konwergencji w teorii wzrostu gospodarczego (Concepts of Convergence in the Growth Theory). Nierówności Społeczne a Wzrost Gospodarczy, 8, 253-266.

Pietrzykowski, R. (2014a). Cena ziemi rolniczej jako wskaźnik rozwoju regionalnego (Price of agricultural land as an indicator of regional development). Referat z IX Kongresu Ekonomistów Polskich.

Pietrzykowski, R. (2014b). Rozwój gospodarczy a ceny ziemi rolniczej na przykładzie wybranych państw z Unii Europejskiej (Economic development and agricultural land prices in selected countries of the European Union). Prace Naukowe Uniwersytetu Ekonomicznego we Wrocławiu, 348, 285-295.

Prokurat, S. (2017). Ekonomiczne i prawne aspekty obrotu ziemią w Polsce na tle rynku europejskiego. (Economic and legal aspects of land turnover in Poland compared to the European market). Ekonomia Wroclaw Economic Review, 23/3, 135-158.

Próchniak, M. (2006). Realna konwergencja typu beta $(\beta)$ i sigma $(\sigma)$ w świetle badań empirycznych (Real beta $(\beta)$ and sigma $(\sigma)$ convergence. The review of empirical studies). Zeszyty Naukowe Szkoły Głównej Handlowej. Kolegium Gospodarki Światowej, 20, 74-91.

Rynek Ziemi Rolniczej. Stan i perspektywy. Analizy rynkowe (Agricultural land market. Condition and prospects. Market analysis). (2010). Wyd. IERiGŻ, Warszawa.

Rynek Ziemi Rolniczej. Stan i perspektywy. Analizy rynkowe (Agricultural land market. Condition and prospects. Market analysis). (2017). Wyd. IERiGŻ, Warszawa.

Sikorska, A. (2013). Obrót ziemią a przemiany agrarne w indywidualnym rolnictwie (Land Turnover and Agrarian Changes in Individual Farming). Zagadnienia Ekonomiki Rolnej, 1, 8-21.

Tylec, T. (2017). Konwergencja gospodarcza na poziomie regionalnym w wybranych grupach państw Unii Europejskiej w latach 2000-2014. (Economic Convergence in Selected Groups of the European Union's Member States During the Period of 2000-2014). Studia Ekonomiczne. Zeszyty Naukowe Uniwersytetu Ekonomicznego w Katowicach, 319, 259-267.

Weil, E. (2003). Determinanty kształtujące cene ziemi rolnej (The determinants forming of agricultural land prices). Roczniki Akademii Rolniczej w Poznaniu - Seria Ekonomia, CCCLVIII(2), 153-168.

Wyrzykowski, P. (2015). Konwergencja cen żywności w Unii Europejskiej (Food price convergence in European Union). Roczniki Naukowe SERiA, 17(4), 356-361.

Zawojska, A. (2012). Zróżnicowanie i konwergencja cen dóbr konsumpcyjnych w integrującej się Europie (Differences and convergence of consumer prices in the integrating Europe). Roczniki Ekonomii Rolnictwa $i$ Rozwoju Obszarów Wiejskich, 99(2), 16-32.

\section{Do cytowania / For citation:}

Twardowska A. (2019). Konwergencja typu sigma cen gruntów rolnych w państwach Unii Europejskiej. Problemy Rolnictwa Światowego, 19(1), 133-143; DOI: 10.22630/PRS.2019.19.1.12

Twardowska A. (2019). Sigma Convergence of Agricultural Land Prices in European Union Countries (in Polish). Problems of World Agriculture, 19(1), 133-143; DOI: 10.22630/PRS.2019.19.1.12 